Court of the county upon the form furnislied him as hereinafter provided, for which registration he shall be paid fifty cents by the applicant.

7. 'l'hat it siall be the duty of the Nortl Ca rolina State Nurses' Association to prescribe a proper form of the certificate required by this act, and to furnish the same in suflicient quantity suitably bound in a look and labelled "Register of Trained Nurses" to the Clerk of the court of each county in the State.

8 . 'The satid Board of Eximiners shrall lave power after twenty-hays' notice of the ehirges preferred and the time and place of meeting, and after a full and fair hearing on the same, by a majority vote of the whole board, to revoke any license isisued ly them for gross incompetency, dishonesty, habitual intemperance, or any other act in the judgment of the buard derogatory to the morals or standing of the profession of nursing. Upon the revocation of a license or certificate, the name of the holder thereof shall be stricken from the roll of registered nurses in the hands of the secretary of the board, and upon notification of suel action by said secretary by the Clerk of the court from his register.

9. That any person proeuring lieense under this aet by false representation, or who shall refuse to surrender a license which has been revoked in the manner prescribed in Seetion s, or who shall use the title "Registered Nurse" or "IR.N." without first having obtained license to do so, shall be guilty of a mischemennor, and upon conviction shall be fined not more than fifty dollars or imprisommont not exceeting thirty dayss.

10. 'That nothing in this act slatl in any manner whatever "urtail or abridge the right ant privilege of any person to pursue the voeation of a nurse, whether trained or unt rained, registered or not registered.

11. 'lhat this aret shall be in fore from and after its ratification.

\title{
NEW JERSEY BILL
}

\section{liecanne a law April 7,1903}

1. Any graduate nurse desiring to practise the profession of a trained nurse must first obtain a license from the Clerk of the connty in which such applicant resides, and the Clerk thereof is herelyy authorized to issue sueh license, provided s:lid applicant shall present to him a diploma awarded by a training-school eonnected with a hospital of this state where at lenst two-years' practieal and theoretieal traning is required lefore its students are graduated as trained murses; if the said diphoma dues not show the term required by the training-school awarding the same, then the applicant must file witl the County Clerk an affidavit made by the secretary of said training-sehool, or the president of the faeulty therenf, setting forth the term of practical and theoretical training required by said training-school of its stndents before they are graluated as trained nurses.

2. Any person heretofore awarded a diploma of a graduate nurse by trainingseluowls of this state other than those mentioned in the preceding section may apply to the Clerk of the county in which suels appli'ant resides for the license provided by this act, and such clerk is leereby authorizel to issue same if the person making such application was awarded such diploma upon the completion of at least two years' practical and theoretical training in nursing.

3. Any gratuate nurse lrolding a diploma of a trained nurse awarded by a training-school of another State may obtain a license to practise such profession 
in this state provided the training-school allarding such diploma shall rewuire the satme culliticuations of its griduate nurses as are provided for applicants of this State; if the chiphona of sait mon-resident applieant does not show the course of training required by the trining-sehool atwarding the same, then the applicant shall file an allihtivit of the secretary of the hospital connected with said training-school or the presitent thereof, setting forth the requirements of said training-school before diplonias are awarted to its sturlents; graduate nurses residing ont of the state and secking the license herein provided may apply to the clerk of any county in this state upon boing identified by a resident thereof.

4. Before any license slaall be issued to an applicant under the provisions of this act, a fee of fifty cents shall be paid to the Clerk issuing the salme.

5. The sitill license shall be in form as follows:

"STite of New Jerser, $\}$ ss.
County of

"To whem it may conecrn, grecting:

"This is to certify thitt.............. (giving place of residence) is authorized to practise the profession of a graduate nurse in the state of New Jersey in aterordance with the laws thereof.

"In withess where of I lrave hereto attiaclied iny name and official seal this ....... thy of ....... Anno bomini one thousand nine bundred and . . ...

\section{[s.3.1.]}

"...........

"Clerk of the Cominy. . . ."

6. Any person violating any of the provisions of this act shall for erery offence forfeit and pay the sum of lifty dollars, to be used for and recovered lyy the l'rosecutor of the Pleas for the use of the comnty in which such of ene is eommitted. l'rovided, howerer, that this act slatl not apply to griduate nurses, residents of at foreign state, who shall have at least two-years' proctical and theoretical training, or have graduated from a training-sehool connected with a pouldic hospital, who shall visit. this state ats a companion or nurse for a non-resident of this State sojomming within the state, or who shall he called in a case by any resident physician of this state. l'rovideal, also, that nothing in this act shall be held or construed as preventing or in any way intertering with any person or persons practising the profession or husinesis of nursis or mursing without obtaining a license for that purpose if they do not alvertise or hold themselves out as a grahate nurse.

\section{NEW YORK BILL}

Became a law April 27, 1903

206. Who ma!y Practice as Registered Nurses.-Any resident of the State of New York, being over the age of twenty-one years and of good moral character,

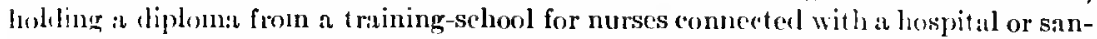
itarium giving a comrse of at least two years, and registered by the Regents of the University of the state of New York as maintaining in this and ot leer respects proper st:indards, all of which shall be determined by the said lacgents, and who shall have received from the said Regents a certificate of his or her qualifications to practise as a registered nurse, shall be styled and known as a registered nurse, 
and no other person shall assume such title, or use the abbreviation "R.N." or any other words, letters, or figures to indicate that the person using the same is sucl a registered nurse. Before beginning to praetise nursing every such registered nurse shall cause such certificate to be reeorded in the County Clerk's office of the county of his or her residence with an aflidavit of his or her identity as the person to whom the same was so issued and of his or her place of residence within such county. In the month of January, nineteen hundred and six, and in every thirty-sixth inonth thereafter, every registered nurse shall again cause his or her certificate to be recorded in the said County Clerk's oflice, with an afliclavit of his or her identity as the person to whom the same was issued, and of his or her place of residence at the time of such re-registration. Nothing contained in this act shall be considered as conferring any authority to practise nedicine or to undertake the treatment or cure of disease in violation of article eight of this cliapter.

207. Bourd of Exuminers; Examination; Fes.- Upon the taking effect of this act the New York State Nurses' Association shall nominate for eximiners ten of their members who have had not less than five years' experience in their profossion, and at each annual meeting of said association thereafter two otler candidates. The legents of the Lniversity of the state of New lork shall appoint a hoard of five examiners from such list. One member of said board shall be appointed for one year, one for two years, one for three years, one for four yeurs, and one for five years. Upon the expiration of the term of ollice of ally examiner the said liegents sliall likewise till the vacancy for a term of five years and until his or her suc'cessor is chosen. An unexpired term of an examiner caused by death, resignation, or otherwise shall be filled by the Regents in the same manner as an original appointment is made. The sail Regents, with the advice of the lioard of Examiners ahove provided for, shall malie rules for the exanination of nurses applying for certilication muler this act, and shall charge for examination and for certitication a fee of five dollars to meet the actual expenses, and slall report annually their receipts and expenditures under the provisions of this act to the state Comptroller, and pay the balance of receipts over expenditures to the State 'Ireasurer. 'The said Regents may revoke any such eertificate for sufficient cause after written notice to the holder thereof and hearing thereon. No person shall thereafter practise as a registered nurse under any such revoked certificate.

20s. Waiver of Examinations.-I'Te legents of the University of the State of New York may, upon the recommenclation of saicl lBoard of Examiners, waive the examination of any persons possessing the qualifications nentioned in section two hundred and six, who shall have been graduated before, or who are in taining at the time of, the passage of this act and shall hereafter he grathated, and of sucli persons now engaged in the practice of nursing as lave had threc-years' experience in a general hospital prior to the passage of this act, who shall apply in writing for such certilicate within three years after the passage of this act, and shall also grant a certificate to any nurse of good moral charaeter, who has been engaged in the actual practice of nursing for not less than three years next prior to the passage of this act, who shall satisfactorily pass an exanination in practical musing within three years hereafter.

209. Violations of this Article.-Any violation of this article sluall be a misdemeanor. When any prosecution under this article is made on complaint of the New York State Nurses' Association, the eertificate of incorporation of which was filed and recorded in the offiee of the Secretary of State on the second day of April, 
nincteen hundred and two, the fines collected shall be paid to sidil association, and any excess in the amount of fines so paid over the expenses incurred by said association in enforeing the provisions of this article shall be paid at the end of each year to the Treasurer of the state of New York.

2. Article twelve of the pmblic liealth law, consisting of sertions two humber and ten to two lumdred and twenty, inclusive, is locroly remunluered as article thirtere of satil law.

3. "This act shall take effect immediately.

\section{VIRGINIA BILL}

Became a law May, 190:3

1. Be it cnected by the Cieneral Assembly of l'irginia, l'hit within sixty days after the passige of this act the (aweroor of this sitate shall appoint a sitate limard

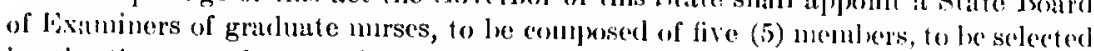
by the deveruor from twelse (12) mominations sulmited to lim ly the virginia State Association of (imathate Nurses. One of the members of this locapd slatl be designated to holel oflice one year, one for two yeals, ome for three yeits, one for four yours, one for five years; and thereafter, mpent the expintion af the term of ollice

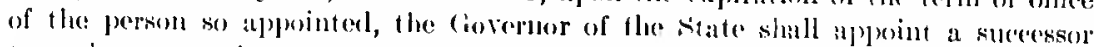

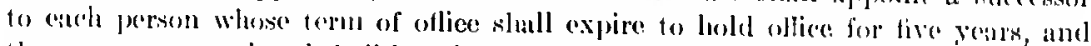
the person so appointed shatl be solected by the fovernor from a hist of seven nominations submited to him hy the Virginia Nitate Assoniation of Cimaduate Nurses. In case appointment of a suceessor is not mate before the expiration of the term of any momber, such member shatl loold ofliee unt il a suceessour is appointed and

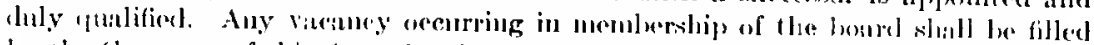
by the ciovernor of this state for the unexpired torm of such mombershij).

2. "The members of fle sitate Board of lexaminers of registered murses slatl, before entering on the discharge of their duties, make and lile with the fereretary

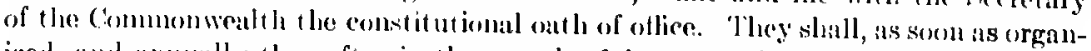
ized, and ammully therester in the montlo of damury, clect from their mumber a presiclent and a secetary, who shall be the thessurer. 'The treasurer, hefore enter-

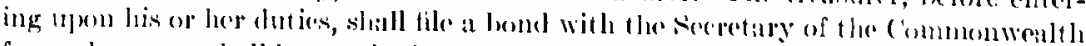

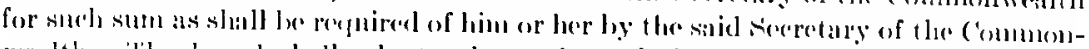

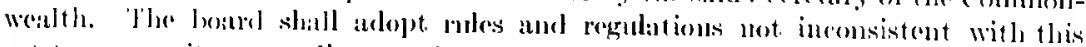

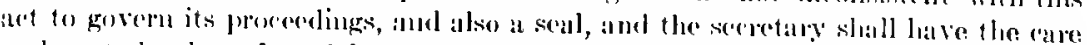

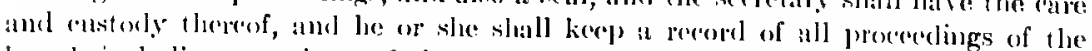

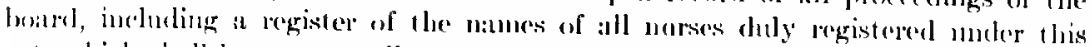

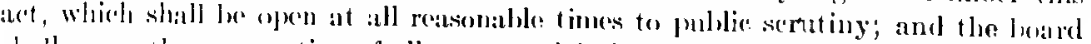
shatl cause the prosecention of all porsons violating any of the povisions of this act,

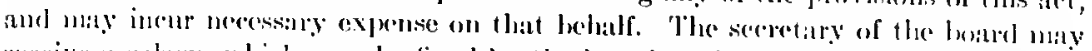

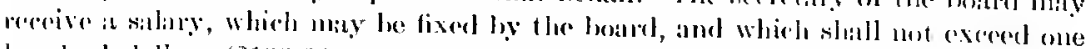

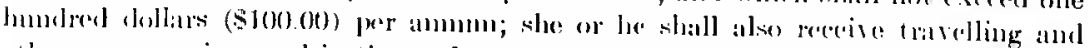

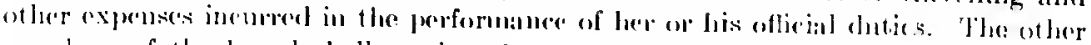

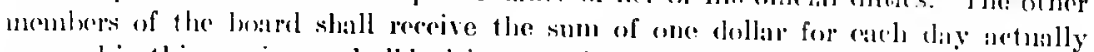

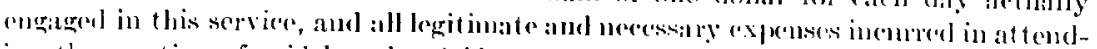

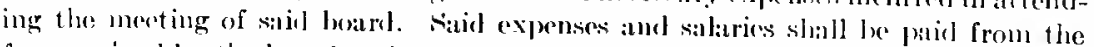
fees received hy the bo:ard under the provisions of this act, and ne pant of the salary 